medRxiv preprint doi: https://doi.org/10.1101/2021.04.12.21255343; this version posted April 13, 2021. The copyright holder for this preprint

(which was not certified by peer review) is the author/funder, who has granted medRxiv a license to display the preprint in perpetuity.

All rights reserved. No reuse allowed without permission.

\title{
Long COVID In Adults at 12 Months After Mild-to-Moderate SARS-CoV-2 Infection
}

Paolo Boscolo-Rizzo ${ }^{1}$, Francesco Guida ${ }^{1}$, Jerry Polesel ${ }^{2}$, Alberto Vito Marcuzzo ${ }^{1}$, Vincenzo Capriotti ${ }^{3}$, Andrea

$D^{\prime}$ Alessandro ${ }^{1}$, Enrico Zanelli ${ }^{1}$, Riccardo Marzolino ${ }^{1}$, Chiara Lazzarin ${ }^{1}$, Paolo Antonucci ${ }^{1}$, Erica Sacchet ${ }^{1}$, Margherita Tofanelli $^{1}$, Daniele Borsetto ${ }^{4}$, Nicoletta Gardenal ${ }^{1}$, Martino Pengo ${ }^{5}$, and Giancarlo Tirelli ${ }^{1}$

${ }^{1}$ Department of Medical, Surgical and Health Sciences, Section of Otolaryngology, University of Trieste, Trieste, Italy

${ }^{2}$ Unit of Cancer Epidemiology, Centro di Riferimento Oncologico di Aviano (CRO) IRCCS, Aviano, Italy

${ }^{3}$ Department of Neurosciences, Section of Otolaryngology, Papa Giovanni XXIII General Hospital, Bergamo, Italy

${ }^{4}$ Department of ENT, Addenbrooke's Hospital, Cambridge University Hospitals NHS Foundation Trust, Cambridge, United Kingdom

${ }^{5}$ Department of Cardiovascular, Neural and Metabolic Sciences, Istituto Auxologico Italiano IRCCS, Ospedale San Luca, Milano, Italy

\section{Abstract}

Background. In a proportion of patients recovered from the acute COVID-19 phase, a variable range of symptoms has been observed to persist for at least 6-months.

Objectives. The main aim of this study was to evaluate the prevalence of COVID-related symptoms 12-months after the onset of mild-to-moderate disease.

Methods Prospective study based on structured questionnaires and additional outcomes.

Results $304 / 354$ patients completing the survey at baseline also completed the follow-up interview (85.9\%; median [range] age, 47 [18-76] years; 185 [60.9\%] women). Persistence of at least one symptom at 12-months follow-up was reported by 161 patients (53.0\%). The most commonly reported symptom of long COVID was felt tired ( $n=83,27.3 \%)$, followed by smell or taste impairment $(n=67,22.0 \%)$, shortness of breath $(n=39,12.8 \%)$ and muscle pain $(n=28,9.2 \%)$. Being females (OR=1.64; 95\% Cl: 1.00-2.70), aged between $40-54(\mathrm{OR}=1.92 ; 95 \% \mathrm{Cl}: 1.07-3.44)$, having a $\mathrm{BMI} \geq 25$ $(\mathrm{OR}=1.67 ; 95 \% \mathrm{Cl}: 1.00-2.78)$, and experiencing more symptoms during the acute phase of the disease (OR=8.71 for $\geq 8$ 
medRxiv preprint doi: https://doi.org/10.1101/2021.04.12.21255343; this version posted April 13, 2021. The copyright holder for this preprint (which was not certified by peer review) is the author/funder, who has granted medRxiv a license to display the preprint in perpetuity. All rights reserved. No reuse allowed without permission.

symptoms; 95\% Cl: 2.73-27.76) were associated with long COVID. Persistence of symptoms showed a significant impact on quality of life $(p<0.0001)$ and depression scale scores $(p=0.0102)$.

Conclusion More than half of patients with previous mild-to-moderate symptomatic COVID-19 complained the persistence of at least one symptom 12-months after the onset of the illness.

Key words: COVID-19; chronic COVID syndrome; long COVID; long haulers; SARS-CoV-2 
medRxiv preprint doi: https://doi.org/10.1101/2021.04.12.21255343; this version posted April 13, 2021. The copyright holder for this preprint

(which was not certified by peer review) is the author/funder, who has granted medRxiv a license to display the preprint in perpetuity.

All rights reserved. No reuse allowed without permission.

Funding: None

Conflict of interest: The authors declare that they have no conflicts of interest

Availability of data and material: The authors confirm that the data supporting the findings of this study are available within the article

Code availability: not applicable

Author Contributions: Drs Boscolo-Rizzo and Guida had full access to all of the data in the study and take responsibility for the integrity of the data and the accuracy of the data analysis

Concept and design: Drs Boscolo-Rizzo, Guida, Pengo and Tirelli

Acquisition, analysis, or interpretation of data: Drs Boscolo-Rizzo, Guida, Polesel, Marcuzzo, Antonucci, Capriotti, Sacchet, D’Alessandro, Zanelli, Marzolino, Lazzarin, Tofanelli, Gardenal, Borsetto

Drafting of the manuscript: Drs Boscolo-Rizzo, Guida, Polesel, Pengo, Tirelli

Critical revision of the manuscript for important intellectual content: Drs Boscolo-Rizzo, Guida, Polesel, Borsetto,

Pengo, Tirelli

Statistical analysis:?Polesel

Supervision: Drs Boscolo-Rizzo and Tirelli

Ethics approval: The study was approved by the Ethics Committee of the Friuli Venezia Giulia Region (CEUR-2020-Os156)

Informed consent: Additional informed consent was obtained from all individual participants for whom identifying information is included in this article 
medRxiv preprint doi: https://doi.org/10.1101/2021.04.12.21255343; this version posted April 13, 2021. The copyright holder for this preprint

(which was not certified by peer review) is the author/funder, who has granted medRxiv a license to display the preprint in perpetuity.

All rights reserved. No reuse allowed without permission.

\section{Introduction}

Since the first cases in China in December 2019, coronavirus disease 2019 (COVID-19), caused by severe acute respiratory syndrome coronavirus 2 (SARS-CoV-2) has spread globally causing a pandemic [1]. SARS-CoV-2 infection can cause a wide array of symptoms ranging from mild to severe or fatal forms with a substantial fraction of cases remaining asymptomatic carries [2]. In symptomatic subjects, the most prevalent symptoms are cough, fever, fatigue, smell or taste impairment, myalgias, and gastrointestinal symptoms [3].

Furthermore, it has been observed that in a proportion of patients recovered from the acute phase, a variable range of symptoms may persist for a long time [4,5] and the persistence of symptoms has a significant impact on healthrelated quality of life (QoL) [6].

There is still no consensus on how to call this condition: the names "chronic COVID", "chronic COVID syndrome", "long haulers", "long COVID" have been used with the latter being the most widespread among patients and in the literature $[7,8]$. Also, there is a lack of a clear definition and criteria to identify this condition. Mahase defined it as: "illness in people who have either recovered from COVID-19 but are still report lasting effects of the infection or have had the usual symptoms for far longer than would be expected" [9]. A similar condition has developed during the other coronaviruses' outbreaks, i.e., severe acute respiratory syndrome coronavirus (SARS-CoV) and Middle East respiratory syndrome coronavirus (MERS-CoV) [10].

An increasing number of studies have been focused on long COVID, but they have mainly been concentrated on previously hospitalized severe COVID-19 patients reporting symptoms up to 6-months after illness [5,11-14]. The main aim of this study was to evaluate the prevalence of COVID-related symptoms 12-months after the onset of mildto-moderate disease. 
medRxiv preprint doi: https://doi.org/10.1101/2021.04.12.21255343; this version posted April 13, 2021. The copyright holder for this preprint

(which was not certified by peer review) is the author/funder, who has granted medRxiv a license to display the preprint in perpetuity.

All rights reserved. No reuse allowed without permission.

\section{Materials and Methods}

\section{Subjects}

We conducted a prospective study on mild-to-moderate symptomatic adult patients consecutively assessed at Cattinara University Hospital, Trieste, Italy between March 1 and March 31, 2020, who tested positive for SARS-CoV-2 RNA by polymerase chain reaction (PCR) on nasopharyngeal and throat swabs performed according to World Health Organization recommendation [15]. All patients were initially home-isolated with mild-to-moderate symptoms. Patients were considered mildly symptomatic if they had less severe clinical symptoms with no evidence of pneumonia, not requiring hospitalization, and therefore considered suitable for being treated at home. As this study was within a research project a imed to assess the prevalence of chemosensory dysfunction in patients with SARS-CoV2 infection[16], patients with a history of previous trauma, surgery or radiotherapy in the oral and nasal cavities, allergic rhinitis or rhinosinusitis, previous olfactory or gustative dysfunction, or psychiatric or neurological diseases, were excluded from the study.

$354(71.4 \%)$ of the 496 eligible patients completed the baseline telephone interview administrated within 3 weeks after the first positive swab performed between $1^{\text {st }}-31^{\text {st }}$ March 2020 . The median time from symptoms onset to SARS-CoV-2 testing was 7 days (interquartile range, 4-12 days). All patients completing the baseline interview were phoned from $5^{\text {th }}$ to $22^{\text {nd }}$ March 2021, so that all patients were recontacted 12-months after the onset of symptoms; in case of a non-response, patients were re-contacted twice.

\section{Questionnaires}

All patients were asked the same questions. Baseline demographic and clinical data, obtained at the time of acute illness or retrospectively within 30-day from the first positive swab, were collected through ad hoc questions administered by telephone interview and included gender, age, self-reported height and weight, smoking and alcohol habits, and the following co-morbidities: immunosuppression, diabetes, cardiovascular diseases, active cancer, chronic respiratory disease, kidney disease, liver disease. Obesity was defined as having a body mass index (BMI) $\geq 30$. Symptoms were assessed through ad hoc questions and structured questionnaire, i.e., the Acute Respiratory Tract Infection Questionnaire (ARTIQ). In addition, during the follow-up interview patients were asked about their general health perception and the presence of depression. Briefly, a single item was used to assess general health 
medRxiv preprint doi: https://doi.org/10.1101/2021.04.12.21255343; this version posted April 13, 2021. The copyright holder for this preprint (which was not certified by peer review) is the author/funder, who has granted medRxiv a license to display the preprint in perpetuity. All rights reserved. No reuse allowed without permission.

perceptions. Patients were asked to rate their overall health on a scale of $0-10$, with 0 representing 'worst health' and 10 representing perfect health according to Cleary et al. [17]. Patients were also asked "on a scale of 0-10, with zero being no depression and 10 being the worst depression you can imagine, how would you rate the worst depression you have now?"[18].

\section{Statistical analysis}

Symptom prevalence was expressed as percentage of total patients, and $95 \%$ confidence interval ( $\mathrm{Cl}$ ) were calculated using Clopper-Pearson method; differences in prevalence were evaluated through Fisher's exact test. Odds ratio (OR) of symptoms' persistence and corresponding 95\% confidence intervals $(\mathrm{Cl})$ were calculated through unconditional logistic regression model, adjusting for sex, age and number of symptoms during the acute Covid-19 phase. To account for potential bias of sex and age, differences in mean value of quality of life and depression were tested through the analysis of variance (ANOVA). Analyses were performed using R 3.6. and statistical significance was claimed for $\mathrm{p}<0.05$ (two-tailed). 
medRxiv preprint doi: https://doi.org/10.1101/2021.04.12.21255343; this version posted April 13, 2021. The copyright holder for this preprint

(which was not certified by peer review) is the author/funder, who has granted medRxiv a license to display the preprint in perpetuity.

All rights reserved. No reuse allowed without permission.

\section{Results}

Of 354 patients completing the survey at baseline, 304 also completed the 12-months follow-up survey (85.9\%).

Baseline socio-demographic and clinical characteristics of 304 patients are reported in Table 1. The median age of the

study cohort was 47 years (range 18-76 years). There was a female preponderance with 185 out of 304 being females

(60.9\%). Associated co-morbidities were reported by 98 cases $(32.3 \%)$ with the most common being obesity $(n=36$,

$11.8 \%)$ followed by cardiovascular disease $(n=26,8.6 \%)$ and chronic respiratory disease $(n=21,6.9 \%)$.

The median time to achieving a negative swab was 23 days (interquartile range, 15-32 days). Figure 1 and Supplementary Table 1 report the prevalence of symptoms in the acute phase of COVID-19 and at 12-months followup. During the acute phase of COVID-19 the most frequently reported symptoms were fever $(n=232,76.3 \%)$, felt tired $(n=216,71.1 \%)$, smell impairment $(n=201,66.1 \%)$, taste impairment $(n=198,65.1 \%)$ and joint pain $(n=181,59.5 \%)$.

Persistence of at least one symptom at 12-months follow-up was reported by 161 patients (53.0\%). The symptom that most frequently persisted at 12-months was felt tired $(n=83,27.3 \%)$, followed by smell or taste impairment ( $n=67$, $22.0 \%)$ with smell being altered in 62 patients $(20.4 \%)$ and taste in $46(15.1 \%)$, shortness of breath $(n=39,12.8 \%)$ and muscle pain $(n=28,9.2 \%)$.

The risk of symptom's persistence at 12-months follow-up was trendy higher in females (OR=1.64; 95\% Cl: 1.00-2.70; $\mathrm{p}=0.0505)$, and significantly higher in subjects aging between 40-54 (OR=1.92;95\% $\mathrm{Cl}: 1.07-3.44 ; \mathrm{p}=0.0290)$ and in those with a $\mathrm{BMI} \geq 25(\mathrm{OR}=1.67 ; 95 \% \mathrm{Cl}: 1.00-2.78 ; \mathrm{p}=0.0492)$. The presence of 3 to 7 symptoms during the acute phase of the disease resulted associated with a significant higher odd of symptom's persistence after 12-months $(\mathrm{OR}=3.22 ; 95 \% \mathrm{Cl}: 1.01-10.24 ; \mathrm{p}=0.0475)$. This association resulted stronger in those having $\geq 8$ symptoms (OR=8.71; 95\% Cl: 2.73-27.76; $p=0.0003$ ) (Table 2).

In long haulers, 8 patients (5.0\%; 95\% Cl: $2.2-9.6 \%)$ had QoL scores $\leq 5$ and 23 patients (14.3\%; 95\% Cl: 9.3-20.7\%) had a depression score $\geq 5$. Persistence of symptoms 12-months after the onset was associated with worse quality of life $(p<0.0001)$ and worse scores on depression scale $(p=0.0102)$. In particular, quality of life was significantly affected by 
medRxiv preprint doi: https://doi.org/10.1101/2021.04.12.21255343; this version posted April 13, 2021. The copyright holder for this preprint (which was not certified by peer review) is the author/funder, who has granted medRxiv a license to display the preprint in perpetuity. All rights reserved. No reuse allowed without permission.

felt tired $(p<0.0001)$, shortness of breath $(p=0.0015)$ and insomnia $(p=0.0379)$, while felt tired significantly impact on scores on depression scale $(p=0.0082)$ (Table 3). 
medRxiv preprint doi: https://doi.org/10.1101/2021.04.12.21255343; this version posted April 13, 2021. The copyright holder for this preprint

(which was not certified by peer review) is the author/funder, who has granted medRxiv a license to display the preprint in perpetuity.

All rights reserved. No reuse allowed without permission.

\section{Discussion}

To our knowledge, this is the cohort study with longest follow-up duration assessing the prevalence of persistent symptoms in COVID-19 patients. We observed that 12-months after the onset of illness, $53.0 \%$ of patients with mildto-moderate COVID-19 endorsed at least one persistent symptom. A previous investigation in a large cohort of patients with COVID-19 discharged from hospital reported a at least one symptom in $76 \%$ of cases 6 -months after acute infection [12], while in another study, including outpatients with mild disease, approximately $30 \%$ reported persistent symptoms at 6-months [14]. Thus, taking into account that our series included only outpatients with mildto-moderate COVID-19 representing the overwhelming majority of COVID-19 patients [3], the rate of long COVID observed in the present cohort is quite worrying. Although few patients had QoL scores $\leq 5$ and depression score $\geq 5$, the persistence of symptoms 12-months after the onset was associated with worse quality of life and worse scores on depression scale. Recent investigations have observed a significant impairment in QoL in patients previously hospitalized for COVID-19 [6] and a worsening of QoL was described in about one third of patients 6-months after the acute illness [14]. Considering the continued worldwide spread of SARS-CoV-2 infection, the burden of long haulers on the health care systems will be pressing and urged researchers to identify subjects at risk of long COVID for trials of strategies for prevention or treatment and to plan education and rehabilitation services in order to face with the considerable health and economic concerns [4].

In agreement with other evidence, the most commonly reported symptom was fatigue followed by chemosensory dysfunction $[4,5,14]$. Fatigue was reported by $27 \%$ of patients. Previous investigations with long-term follow-up have observed a frequency of this symptom of $14 \%$ [14] to $63 \%$ [12] at 6-months with higher prevalence recorded in a series including only hospitalized subjects. An altered sense of smell or taste was the second more common symptom of long COVID in the present series reported by $22.0 \%$ of subjects. Chemosensory dysfunction has been consistently reported as one of the most predominant symptom during the acute phase of the disease as well as among the most frequent long-lasting symptoms in patients with COVID-19 $[19,20]$ with a higher prevalence in patients with mild-tomoderate disease [21]. Consistently, series including outpatients $[4,14]$ have observed a higher rate of long-term chemosensory impairment compared to those including only patients with severe COVID-19 [12], while one study not using structured questionnaires failed to provide data about the prevalence of altered sense of smell or taste in the context of long COVID syndrome [11]. Furthermore, anosmia was recently reported as one of the symptoms characterizing the long COVID syndrome among a large series of app users [4]. Some authors have speculated that 
medRxiv preprint doi: https://doi.org/10.1101/2021.04.12.21255343; this version posted April 13, 2021. The copyright holder for this preprint

(which was not certified by peer review) is the author/funder, who has granted medRxiv a license to display the preprint in perpetuity.

All rights reserved. No reuse allowed without permission.

mild-to-moderate COVID-19 patients may be affected by nasal-centric viral spread, whereas patients requiring hospitalization may be experiencing a more pulmonary-centric and systemic viral infection thus impacting the prevalence of different symptoms both in acute phase and in the context of long COVID syndrome [22]. However, although all patients in the study had mild to moderate disease without evidence of pneumonia, $13 \%$ still reported shortness of breath at 12-months follow-up interview. Interestingly, an abnormal pulmonary function consisting in an impaired diffusing-capacity was observed in $30 \%$ of patients after the acute phase of mild COVID-19 without pneumonia [23].

In addition to the different settings and timing of symptoms detection, an important source of heterogeneity in reporting the prevalence of symptoms in patients with long COVID is the lack of using a validated questionnaire. To date, no standardized tool has been proposed yet for a uniform and comprehensive evaluation and reporting of symptoms in COVID-19 patients. In the present study ad hoc questions were used as well as a structured questionnaire, the ARTIQ, as it was demonstrated to be a validated tool to assess the severity and functional impacts of acute respiratory tract infections [24].

Experiencing more symptoms at baseline was the most significant factor associated with long COVID. This is in line with recent evidence showing that subjects complaining more than 5 symptoms during the first week of illness are more prone to develop long COVID [4]. Moreover, the prevalence of long haulers was higher in females, patients in their middle age and those with $\mathrm{BMI} \geq 25$. Thus, models to identify patients at risk for long COVID may be developed.

This study has several limitations. First, the absence of a control group may impact on the interpretation of results. The single-centre study design and the relatively small number of sample size may restrict its generalizability. Hospitalized patients were not included in the study. Although this made our cohort more homogeneous, studies comparing the long-term outcomes in inpatients and outpatients are definitely needed. Symptoms were self-reported and based on telephone interview. Though, we tried to perform a comprehensive symptoms assessment by using ad hoc questions and a structured questionnaire, some symptoms may have been undetected. The QoL and depression assessment was performed only at 12-months follow-up. Thus, we were unable to report a worsenig in the QoL and depression scale scores. 
medRxiv preprint doi: https://doi.org/10.1101/2021.04.12.21255343; this version posted April 13, 2021. The copyright holder for this preprint (which was not certified by peer review) is the author/funder, who has granted medRxiv a license to display the preprint in perpetuity. All rights reserved. No reuse allowed without permission.

In conclusion, our study indicates that persistent symptoms of SARS-CoV-2 infection can be detected beyond $12-$ months from the onset of the illness in more than half of patients with mild-to-moderate disease. Identifying patients at risk for prevention and treatment will be critical to improving outcomes and reducing health costs. Finally, a structured and validated questionnaire for the assessment of symptoms in COVID-19 patients is highly desirable to characterize the full clinical spectrum of long COVID and improve the reliability and reproducibility of clinical studies. 
medRxiv preprint doi: https://doi.org/10.1101/2021.04.12.21255343; this version posted April 13, 2021. The copyright holder for this preprint

(which was not certified by peer review) is the author/funder, who has granted medRxiv a license to display the preprint in perpetuity.

All rights reserved. No reuse allowed without permission.

\section{References}

[1] Z. Wu, J.M. McGoogan, Characteristics of and Important Lessons From the Coronavirus Disease 2019 (COVID-19) Outbreak in China: Summary of a Report of 72314 Cases From the Chinese Center for Disease Control and Prevention, JAMA. (2020). https://doi.org/10.1001/jama.2020.2648.

[2] W.J. Wiersinga, A. Rhodes, A.C. Cheng, S.J. Peacock, H.C. Prescott, Pathophysiology, Transmission, Diagnosis, and Treatment of Coronavirus Disease 2019 (COVID-19): A Review, JAMA. 324 (2020) 782-793. https://doi.org/10.1001/jama.2020.12839.

[3] R.T. Gandhi, J.B. Lynch, C. del Rio, Mild or Moderate Covid-19, N. Engl. J. Med. 383 (2020) 1757-1766. https://doi.org/10.1056/NEJMcp2009249.

[4] C.H. Sudre, B. Murray, T. Varsavsky, M.S. Graham, R.S. Penfold, R.C. Bowyer, J.C. Pujol, K. Klaser, M. Antonelli, L.S. Canas, E. Molteni, M. Modat, M. Jorge Cardoso, A. May, S. Ganesh, R. Davies, L.H. Nguyen, D.A. Drew, C.M. Astley, A.D. Joshi, J. Merino, N. Tsereteli, T. Fall, M.F. Gomez, E.L. Duncan, C. Menni, F.M.K. Williams, P.W. Franks, A.T. Chan, J. Wolf, S. Ourselin, T. Spector, C.J. Steves, Attributes and predictors of long COVID, Nat. Med. (2021). https://doi.org/10.1038/s41591-021-01292-y.

[5] A. Carfi, R. Bernabei, F. Landi, Gemelli Against COVID-19 Post-Acute Care Study Group, Persistent Symptoms in Patients After Acute COVID-19, JAMA. 324 (2020) 603-605. https://doi.org/10.1001/jama.2020.12603.

[6] S. van der Sar-van der Brugge, S. Talman, L. Boonman-de Winter, M. de Mol, E. Hoefman, R.W. van Etten, I.C. De Backer, Pulmonary function and health-related quality of life after COVID-19 pneumonia, Respir. Med. 176 (2021) 106272. https://doi.org/10.1016/j.rmed.2020.106272.

[7] A.M. Baig, Chronic COVID syndrome: Need for an appropriate medical terminology for long-COVID and COVID long-haulers, J. Med. Virol. (2020). https://doi.org/10.1002/jmv.26624.

[8] Long COVID: let patients help define long-lasting COVID symptoms, Nature. 586 (2020) 170. https://doi.org/10.1038/d41586-020-02796-2.

[9] E. Mahase, Covid-19: What do we know about "long covid"?, BMJ. 370 (2020) m2815. https://doi.org/10.1136/bmj.m2815.

[10] O. O'Sullivan, Long-term sequelae following previous coronavirus epidemics, Clin. Med. 21 (2021) e68-e70. https://doi.org/10.7861/clinmed.2020-0204.

[11] Q. Xiong, M. Xu, J. Li, Y. Liu, J. Zhang, Y. Xu, W. Dong, Clinical sequelae of COVID-19 survivors in Wuhan, China: a single-centre longitudinal study, Clin. Microbiol. Infect. Off. Publ. Eur. Soc. Clin. Microbiol. Infect. Dis. 27 (2021) 89-95. https://doi.org/10.1016/j.cmi.2020.09.023.

[12] C. Huang, L. Huang, Y. Wang, X. Li, L. Ren, X. Gu, L. Kang, L. Guo, M. Liu, X. Zhou, J. Luo, Z. Huang, S. Tu, Y. Zhao, L. Chen, D. Xu, Y. Li, C. Li, L. Peng, Y. Li, W. Xie, D. Cui, L. Shang, G. Fan, J. Xu, G. Wang, Y. Wang, J. Zhong, C. Wang, J. Wang, D. Zhang, B. Cao, 6-month consequences of COVID-19 in patients discharged from hospital: a cohort study, The Lancet. 397 (2021). https://doi.org/10.1016/S0140-6736(20)32656-8.

[13] H. Klein, K. Asseo, N. Karni, Y. Benjamini, R. Nir-Paz, M. Muszkat, S. Israel, M.Y. Niv, Onset, duration, and persistence of taste and smell changes and other COVID-19 symptoms: longitudinal study in Israeli patients, MedRxiv. (2020) 2020.09.25.20201343. https://doi.org/10.1101/2020.09.25.20201343.

[14] J.K. Logue, N.M. Franko, D.J. McCulloch, D. McDonald, A. Magedson, C.R. Wolf, H.Y. Chu, Sequelae in Adults at 6 Months After COVID-19 Infection, JAMA Netw. Open. $4 \quad$ (2021) e210830. https://doi.org/10.1001/jamanetworkopen.2021.0830.

[15] Technical guidance, (n.d.). https://www.who.int/emergencies/diseases/novel-coronavirus-2019/technicalguidance (accessed March 25, 2020).

[16] P. Boscolo-Rizzo, F. Guida, J. Polesel, A.V. Marcuzzo, P. Antonucci, V. Capriotti, E. Sacchet, F. Cragnolini, A. D'Alessandro, E. Zanelli, R. Marzolino, C. Lazzarin, M. Tofanelli, N. Gardenal, D. Borsetto, C. Hopkins, L.A. Vaira, G. Tirelli, Self-reported smell and taste recovery in COVID-19 patients: a one-year prospective study, MedRxiv. (2021) 2021.03.18.21253862. https://doi.org/10.1101/2021.03.18.21253862.

[17] P.D. Cleary, G. Morrissey, G. Oster, Health-related quality of life in patients with advanced prostate cancer: a multinational perspective, Qual. Life Res. Int. J. Qual. Life Asp. Treat. Care Rehabil. 4 (1995) $207-220$. https://doi.org/10.1007/BF02260860.

[18] S.Z. Pantilat, D.L. O'Riordan, S.L. Dibble, C.S. Landefeld, An assessment of the screening performance of a singleitem measure of depression from the Edmonton Symptom Assessment Scale among chronically ill hospitalized patients, J. Pain Symptom Manage. 43 (2012) 866-873. https://doi.org/10.1016/j.jpainsymman.2011.05.022.

[19] G. Spinato, C. Fabbris, J. Polesel, D. Cazzador, D. Borsetto, C. Hopkins, P. Boscolo-Rizzo, Alterations in Smell or Taste in Mildly Symptomatic Outpatients With SARS-CoV-2 Infection, JAMA. 323 (2020) 2089-2090. https://doi.org/10.1001/jama.2020.6771. 
medRxiv preprint doi: https://doi.org/10.1101/2021.04.12.21255343; this version posted April 13, 2021. The copyright holder for this preprint

(which was not certified by peer review) is the author/funder, who has granted medRxiv a license to display the preprint in perpetuity. All rights reserved. No reuse allowed without permission.

[20] P. Boscolo-Rizzo, J. Polesel, G. Spinato, A. Menegaldo, C. Fabbris, L. Calvanese, D. Borsetto, C. Hopkins, Predominance of an altered sense of smell or taste among long-lasting symptoms in patients with mildly symptomatic COVID-19, Rhinology. 58 (2020) 524-525. https://doi.org/10.4193/Rhin20.263.

[21] D. Borsetto, C. Hopkins, V. Philips, R. Obholzer, G. Tirelli, J. Polesel, P. Boscolo-Rizzo, Self-reported alteration of sense of smell or taste in patients with COVID-19: a systematic review and meta-analysis on 3563 patients, Rhinology. 58 (2020) 430-436. https://doi.org/10.4193/Rhin20.185.

[22] C.H. Yan, F. Faraji, D.P. Prajapati, C.E. Boone, A.S. DeConde, Association of chemosensory dysfunction and Covid19 in patients presenting with influenza-like symptoms, Int. Forum Allergy Rhinol. (2020). https://doi.org/10.1002/alr.22579.

[23] X. Mo, W. Jian, Z. Su, M. Chen, H. Peng, P. Peng, C. Lei, S. Li, R. Chen, N. Zhong, Abnormal pulmonary function in COVID-19 patients at time of hospital discharge, Eur. Respir. J. (2020). https://doi.org/10.1183/13993003.01217-2020.

[24] R. Aabenhus, H. Thorsen, V. Siersma, J. Brodersen, The development and validation of a multidimensional sumscaling questionnaire to measure patient-reported outcomes in acute respiratory tract infections in primary care: the acute respiratory tract infection questionnaire, Value Health J. Int. Soc. Pharmacoeconomics Outcomes Res. 16 (2013) 987-992. https://doi.org/10.1016/j.jval.2013.06.011. 


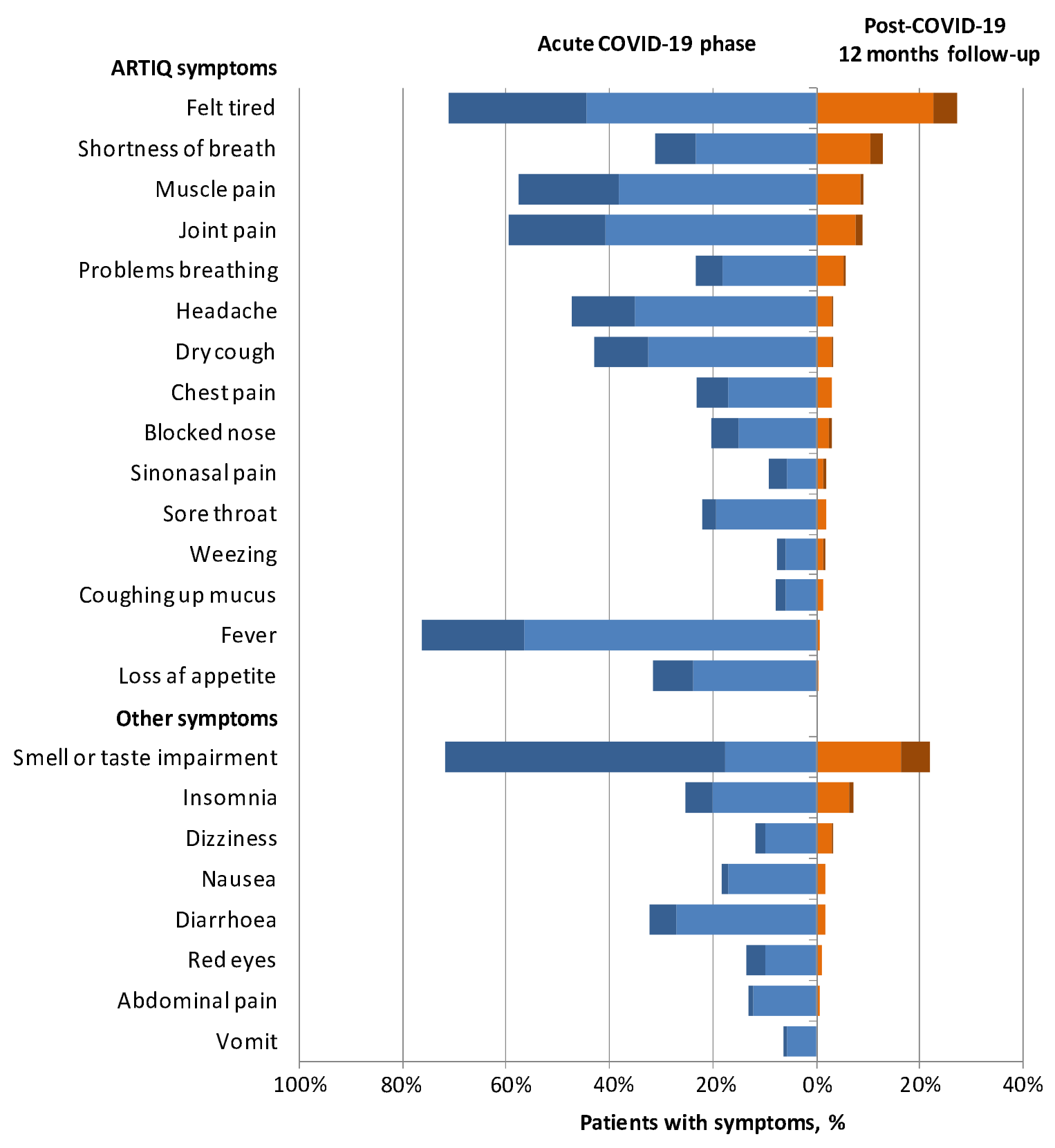

\section{Figure 1. COVID-19-Related Symptoms}

The figure reports the percentages of patients with COVID-19-related symptoms during the acute phase of illness (blue) and at 12-months follow-up (orange) according to severity (light=mild; dark=severe)

ARTIQ: Acute Respiratory Tract Infection Questionnaire


medRxiv preprint doi: https://doi.org/10.1101/2021.04.12.21255343; this version posted April 13, 2021. The copyright holder for this preprint (which was not certified by peer review) is the author/funder, who has granted medRxiv a license to display the preprint in perpetuity. All rights reserved. No reuse allowed without permission.

Table 1. Sociodemographic and clinical characteristics of 304 patients positive for COVID-19

\begin{tabular}{|c|c|c|}
\hline & $\mathbf{n}$ & (\%) \\
\hline \multicolumn{3}{|l|}{ Gender } \\
\hline Male & 119 & (39.1) \\
\hline Female & 185 & $(60.9)$ \\
\hline \multicolumn{3}{|l|}{ Age (years) ${ }^{a}$} \\
\hline$<40$ & 93 & $(30.6)$ \\
\hline $40-54$ & 119 & (39.1) \\
\hline$\geq 55$ & 92 & $(30.3)$ \\
\hline \multicolumn{3}{|l|}{ Smoking habits } \\
\hline Never & 179 & $(58.9)$ \\
\hline Former & 74 & $(24.3)$ \\
\hline Current & 51 & $(16.8)$ \\
\hline \multicolumn{3}{|l|}{ Drinking habits } \\
\hline Never & 202 & $(66.5)$ \\
\hline Former & 30 & (9.9) \\
\hline Current & 72 & $(23.7)$ \\
\hline \multicolumn{3}{|l|}{$\mathrm{BMI}\left(\mathrm{kg} \mathrm{m}^{-2}\right)$} \\
\hline$<25$ & 170 & $(55.9)$ \\
\hline$\geq 25$ & 134 & $(44.1)$ \\
\hline \multicolumn{3}{|l|}{ Comorbidity } \\
\hline None & 206 & $(67.8)$ \\
\hline Any & 98 & $(32.2)$ \\
\hline Obesity & 36 & $(11.8)$ \\
\hline Cardiovascular disease & 26 & $(8.6)$ \\
\hline Chronic respiratory disease & 21 & $(6.9)$ \\
\hline Immunosuppression & 18 & $(5.9)$ \\
\hline Diabetes & 10 & $(3.3)$ \\
\hline Cancer & 5 & $(1.6)$ \\
\hline Liver disease & 5 & $(1.6)$ \\
\hline Kidney disease & 2 & $(0.7)$ \\
\hline \multicolumn{3}{|l|}{ Time for a negative swab (days) } \\
\hline$\leq 23$ & 157 & $(51.6)$ \\
\hline$>23$ & 147 & $(48.4)$ \\
\hline
\end{tabular}

BMI: body mass index

${ }^{a}$ Median age (IQR): 47 years $(37-56)$ 
medRxiv preprint doi: https://doi.org/10.1101/2021.04.12.21255343; this version posted April 13, 2021. The copyright holder for this preprint (which was not certified by peer review) is the author/funder, who has granted medRxiv a license to display the preprint in perpetuity. All rights reserved. No reuse allowed without permission.

Table 2. Odds ratio and corresponding 95\% confidence interval for symptoms persistence at 12-months follow-up according to sociodemographic and clinical characteristics in 304 patients positive for COVID-19

\begin{tabular}{|c|c|c|c|c|c|c|}
\hline & \multicolumn{4}{|c|}{ Symptoms persistence } & \multirow{3}{*}{ OR $(95 \% \mathrm{CI})^{a}$} & \multirow{3}{*}{ Wald $\chi^{2}$} \\
\hline & \multicolumn{2}{|c|}{ Yes } & \multicolumn{2}{|c|}{ No } & & \\
\hline & $\mathbf{n}$ & $(\%)$ & $\mathbf{n}$ & $(\%)$ & & \\
\hline \multicolumn{7}{|l|}{ Gender } \\
\hline Male & 41 & $(42.9)$ & 68 & $(57.1)$ & Reference & \\
\hline Female & 110 & $(59.5)$ & 75 & $(40.5)$ & $1.64(1.00-2.70)$ & $p=0.0505$ \\
\hline \multicolumn{7}{|c|}{ Age (years) } \\
\hline$<40$ & 39 & (41.9) & 54 & $(58.1)$ & Reference & \\
\hline $40-54$ & 73 & $(61.3)$ & 46 & (38.7) & $1.92(1.07-3.44)$ & $p=0.0290$ \\
\hline$\geq 55$ & 49 & $(53.3)$ & 43 & $(46.7)$ & $1.56(0.84-2.90)$ & $p=0.1555$ \\
\hline \multicolumn{7}{|c|}{ Smoking habits } \\
\hline Never & 96 & $(53.6)$ & 83 & $(46.4)$ & Reference & \\
\hline Ever & 65 & $(52.0)$ & 60 & $(48.0)$ & $0.93(0.57-1.53)$ & $p=0.7847$ \\
\hline \multicolumn{7}{|c|}{ Drinking habits } \\
\hline Never & 114 & $(56.4)$ & 88 & $(43.6)$ & Reference & \\
\hline Ever & 47 & $(46.1)$ & 55 & $(53.9)$ & $0.67(0.39-1.14)$ & $p=0.1400$ \\
\hline \multicolumn{7}{|c|}{$\mathrm{BMI}\left(\mathrm{kg} \mathrm{m}^{-2}\right)$} \\
\hline$<25$ & 79 & $(46.5)$ & 91 & $(53.5)$ & Reference & \\
\hline$\geq 25$ & 82 & $(61.2)$ & 52 & $(38.8)$ & $1.67(1.00-2.78)$ & $p=0.0492$ \\
\hline \multicolumn{7}{|c|}{ Comorbidity } \\
\hline None & 100 & $(48.5)$ & 106 & $(51.5)$ & Reference & \\
\hline Any & 61 & $(61.2)$ & 37 & $(37.8)$ & $1.42(0.83-2.43)$ & $p=0.2061$ \\
\hline \multicolumn{7}{|c|}{ Time for a negative swab (days) } \\
\hline$\leq 23$ & 80 & $(51.0)$ & 77 & $(49.0)$ & Reference & \\
\hline$>23$ & 81 & $(55.1)$ & 66 & $(44.9)$ & $1.27(0.78-2.06)$ & $p=0.3415$ \\
\hline \multicolumn{7}{|c|}{ Number of symptoms during acute phase of COVID-19 } \\
\hline$\leq 2$ & 4 & (19.1) & 17 & (89.9) & Reference & \\
\hline $3-7$ & 58 & $(42.0)$ & 80 & $(58.0)$ & $3.22(1.01-10.24)$ & $p=0.0475$ \\
\hline $8+$ & 99 & $(68.3)$ & 46 & (31.7) & $8.71(2.73-27.76)$ & $p=0.0003$ \\
\hline
\end{tabular}

BMI: body mass index

${ }^{a}$ Estimated from unconditional logistic regression model, adjusting for gender, age and number of symptoms during the acute COVID-19 phase. 
medRxiv preprint doi: https://doi.org/10.1101/2021.04.12.21255343; this version posted April 13, 2021. The copyright holder for this preprint (which was not certified by peer review) is the author/funder, who has granted medRxiv a license to display the preprint in perpetuity. All rights reserved. No reuse allowed without permission.

Table 3. Mean value and standard deviation (std) of quality of life ( $0=$ the worst; $10=$ the best) and depression ( $0=$ the best; $10=$ the worst) at 12-months follow-up in 304 patients COVID-19

\begin{tabular}{|c|c|c|c|c|}
\hline & \multicolumn{2}{|c|}{ Quality of life } & \multicolumn{2}{|c|}{ Depression } \\
\hline & Mean (std) & ANOVA $^{\text {a }}$ & Mean (std) & ANOVA $^{\text {a }}$ \\
\hline \multicolumn{5}{|l|}{ Gender } \\
\hline Male & $8.39(1.12)$ & $p=0.0787$ & $1.98(1.63)$ & $p=0.0339$ \\
\hline Female & $8.04(1.61)$ & & $2.52(2.17)$ & \\
\hline \multicolumn{5}{|c|}{ Age (years) } \\
\hline$<40$ & $8.65(1.18)$ & $p=0.0030$ & $2.10(1.68)$ & $p=0.4489$ \\
\hline $40-54$ & $8.01(1.55)$ & & $2.54(2.06)$ & \\
\hline$\geq 55$ & $7.92(1.46)$ & & $2.24(2.17)$ & \\
\hline \multicolumn{5}{|c|}{ Comorbidites } \\
\hline None & $8.29(1.58)$ & $p=0.2125$ & $2.27(2.01)$ & $p=0.3487$ \\
\hline Any & $7.95(1.09)$ & & $2.49(1.93)$ & \\
\hline \multicolumn{5}{|c|}{ Persistent symptoms } \\
\hline None & $8.65(1.30)$ & $p<0.0001$ & $1.94(1.85)$ & $p=0.0102$ \\
\hline Any & $7.75(1.44)$ & & $2.64(2.06)$ & \\
\hline \multicolumn{5}{|c|}{ Persistent shortness of breath } \\
\hline No & $8.30(1.44)$ & $p=0.0015$ & $2.25(1.95)$ & $p=0.3525$ \\
\hline Yes & $7.36(1.20)$ & & $2.72(2.24)$ & \\
\hline \multicolumn{5}{|c|}{ Persistent felt tired } \\
\hline No & $8.45(1.28)$ & $p<0.0001$ & $2.10(1.79)$ & $p=0.0082$ \\
\hline Yes & $7.46(1.62)$ & & $2.87(2.37)$ & \\
\hline \multicolumn{5}{|c|}{ Persistent insomnia } \\
\hline No & $8.23(1.46)$ & $p=0.0379$ & $2.26(1.98)$ & $p=0.1429$ \\
\hline Yes & $7.50(1.10)$ & & $3.00(2.07)$ & \\
\hline \multicolumn{5}{|c|}{ Persistent impairment of sense of smell or taste } \\
\hline No & $8.26(1.46)$ & $p=0.0532$ & $2.22(2.05)$ & $p=0.2084$ \\
\hline Yes & $7.88(1.39)$ & & $2.63(1.75)$ & \\
\hline
\end{tabular}


medRxiv preprint doi: https://doi.org/10.1101/2021.04.12.21255343; this version posted April 13, 2021. The copyright holder for this preprint (which was not certified by peer review) is the author/funder, who has granted medRxiv a license to display the preprint in perpetuity. All rights reserved. No reuse allowed without permission.

Supplementary Table 1. Evolution of COVID-19-related symptoms in 304 patients

\begin{tabular}{|c|c|c|c|c|}
\hline \multirow{2}{*}{ Symptoms } & \multicolumn{2}{|c|}{ Post-COVID-19 12-months follow-up } & \multicolumn{2}{|c|}{ Acute COVID-19 phase } \\
\hline & $\mathbf{n}$ & $\%(95 \% \mathrm{Cl})$ & $\mathbf{n}$ & $\%(95 \% \mathrm{Cl})$ \\
\hline Any symptom & 161 & $53.0(47.2-58.7)$ & 304 & $100(98.8-100)$ \\
\hline \multicolumn{5}{|l|}{ ARTIQ } \\
\hline Felt tired & 83 & $27.3(22.4-32.7)$ & 216 & $71.1(65.6-76.1)$ \\
\hline Shortness of breath & 39 & $12.8(9.3-17.1)$ & 95 & $31.3(26.1-36.8)$ \\
\hline Muscle pain & 28 & $9.2(6.2-13.0)$ & 175 & $57.6(51.8-63.2)$ \\
\hline Joint pain & 27 & $8.9(5.9-12.7)$ & 181 & $59.5(53.8-65.1)$ \\
\hline Problems breathing & 17 & $5.6(3.3-8.8)$ & 71 & $23.4(18.7-28.5)$ \\
\hline Dry cough & 10 & $3.2(1.6-6.0)$ & 131 & $43.1(37.5-48.9)$ \\
\hline Headache & 10 & $3.2(1.6-6.0)$ & 144 & $47.4(41.6-53.1)$ \\
\hline Blocked nose & 9 & $3.0(1.4-5.5)$ & 62 & $20.4(16.0-25.4)$ \\
\hline Chest pain & 9 & $3.0(1.4-5.5)$ & 70 & $23.0(18.4-28.2)$ \\
\hline Sore throat & 6 & $2.0(0.7-4.2)$ & 67 & $22.0(17.5-27.1)$ \\
\hline Sinonasal pain & 6 & $2.0(0.7-4.2)$ & 28 & $9.2(6.2-13.0)$ \\
\hline Weezing & 5 & $1.6(0.5-3.8)$ & 23 & $7.6(4.9-11.1)$ \\
\hline Coughing up mucus & 4 & $1.3(0.4-3.3)$ & 24 & $7.9(5.1-11.5)$ \\
\hline Fever & 2 & $0.7(0.1-2.4)$ & 232 & $76.3(71.1-81.0)$ \\
\hline Loss of appetite & 1 & $0.3(0.0-1.8)$ & 96 & $31.6(26.4-37.1)$ \\
\hline \multicolumn{5}{|l|}{ Other symptoms } \\
\hline Smell impairment & 62 & $20.4(16.0-25.4)$ & 201 & $66.1(60.5-71.4)$ \\
\hline Taste impairment & 46 & $15.1(11.3-19.7)$ & 198 & $65.1(59.5-70.5)$ \\
\hline Insomnia & 22 & $7.2(4.6-10.8)$ & 77 & $25.3(20.5-30.6)$ \\
\hline Dizziness & 10 & $3.2(1.6-6.0)$ & 36 & $11.8(8.4-16.0)$ \\
\hline Diarrhoea & 5 & $1.6(0.5-3.8)$ & 98 & $32.2(27.0-37.8)$ \\
\hline Nausea & 5 & $1.6(0.5-3.8)$ & 56 & $18.4(14.2-23.2)$ \\
\hline Red eyes & 3 & $1.0(0.2-2.9)$ & 41 & $13.5(9.9-17.8)$ \\
\hline Abdominal pain & 2 & $0.7(0.1-2.4)$ & 40 & $13.2(9.6-17.5)$ \\
\hline Vomit & 0 & $0.0(0.0-1.2)$ & 19 & $6.3(3.8-9.6)$ \\
\hline
\end{tabular}

ARTIQ: Acute Respiratory Tract Infection Questionnaire 